\title{
Laste hooldamise ja lastehaiguste ravimise traditsioonilised viisid bessermanidel
}

\begin{abstract}
Jelena Popova
Teesid: Artikkel on kirjutatud aastatel 1986-2000 bessermanide (Loode-Udmurtias Jukamenskoje, Jari, Balezino ja Glazovi rajoonis ning Tšeptsa jõgikonnas elav väike etniline rühm) seas läbi viidud välitööde materjalide põhjal. Artiklis vaadeldakse ema, sünnituse ja vastsündinuga seotud uskumusi, kombeid, hooldusmeetmeid ja ravipraktikaid. Vaadeldud on ka bessermani ämmaemandate ja posijate ravipraktikaid.

Bessermanidel on traditsioonilised ravivõtted säilinud kauem kui naaberrahvastel, eriti laste ravimisega seotud meetmed. Tervikliku mütoloogilise taustaga haigused ja nende ravipraktikad on suuresti unustatud, kuid perekonnas läbiviidavad ravivõtted on säilinud paremini. Lastehaigused ja nende ennetamine on sarnased nagu täiskasvanute haiguste puhul. Tervise saamine täiskasvanult ja "uuestisünnitamise" rituaal on neist olulisimad.
\end{abstract}

Märksõnad: bessermanid, lastehaigused, mütoloogilised haigused, rahvameditsiin, ravitseja, sünnitus, ämmaemand

Bessermanide ettekujutuste kohaselt tagas sündinud lapse heaolu ja õnne sünnituskombestiku täpne järgimine ja lapse õige hooldamine esimestel eluaastatel. Paljud ravi- ja hooldamisvõtted põhinevad arusaamal, et vastsündinu on vastuvõtlikum üleloomulike jõudude ja haigusvaimude mõjule, seetõttu hoolitseti ka lapse füüsilise arengu ja hügieeni eest. Laste hooldamise, lastehaiguste ravimise ja ennetamisega seotud rahvapediaatriat võib vaadelda omaette pärimusharuna. Teadmised lastehaigustest, lapse arengu iseärasustest ja tema kohast maailmas kujutavad endast ratsionaalsete võtete ja mütoloogilis-religioossete ettekujutuste süsteemi. Seepärast on traditsioonilised hooldamismeetodid ja lastehaiguste ravimisviisid jätkuvalt perekonnakombestiku tähtis osa.

Artikkel on kirjutatud aastatel 1986-2000 bessermanide juures läbi viidud välitööde materjalide põhjal (lühend AVM on osutab alljärgneval autori välitööde materjalidele). Bessermanid on väiksearvuline etniline rühm Loode- 
Udmurtia Jukamenskoje, Jari, Balezino ja Glazovi rajoonis Vjatka lisajõe Tšeptsa jõgikonnas. Informantideks olid enamjaolt eakad naised, kes on üldjuhul meestest rohkem seotud sünnituskombestiku, laste ravimise ja hooldamisega. Informantide valik tulenes ka sellest, et varasemad kombekirjeldused puudusid, mistõttu tänapäevaste kommete spetsiifika vaatlemisel tuli kirjeldada ka traditsioonilisi vorme. Ka ei ole vähestes etnograafilistes ülekirjutustes kahjuks mingitki laste kasvatamise ja hooldamise kirjeldust. Teateid olmehügieenist, haigusvaimudest ja ohverdamistest sisaldab vaid Ukani küla vaimuliku K. A. Satrapinski 1854. aastal Vene Geograafia Seltsile esitatud käsikiri (Satrapinski 1854), mille mõned osad on avaldanud Nikolai Nikolski (Nikolski 1919: 77-78).

Bessermanid periodiseerivad väikelapseiga ja lapse hooldamine on eakohane. Vastsündinut on nimetatud roheliseks lapseks, imikuks, rinda imevaks lapseks, pead püstihoidvaks lapseks. Roomama hakkava lapse kohta öeldi inimene neljal jalal, esimeste sammude tegija kohta - leiab jalad. Lapsi pooleteisest kuni kolme aastani nimetati justnagu inimeseks, poolinimeseks, väikelapseks. Elutsükli ja lapse ealise stratifikatsiooniga seotud terminoloogia sarnaneb udmurtide omaga (Pervuhhin 1890: 3; Nikitina 1996: 41), ent perioodide eristamine ja tähistamine on olnud niivõrd suhteline, et isegi ühe pere liikmed tõlgendavad neid erinevalt. Ealine määratlemine on ilmselt alati olnud umbkaudne ja sõltunud konkreetse lapse arengust.

Varases lapsepõlves nõuti karmilt sanitaar-hügieeniliste normide järgimist ja vastsündinu tervise kaitsmist. Selles eas last peeti eriti kaitsetuks ja arvati, et ohtlik aeg kestab hetkeni, kui laps hakkab ise kõndima. Sellepärast oli hooldamise ja kasvatamise põhieesmärkideks lapse elu ja tervise hoidmine, tema füüsiliste ja motoorsete oskuste arendamine. Ettekujutuste kohaselt pandi tulevasele tervisele alus juba lapse sündimisel ja imikueas ning sellest sõltus täiskasvanuea tervis. Arvati, et kõike seda võis tagada lapse tähtsaimaid arenemisperioode saatvate rituaalide ja käitumisnormide järgimisega.

Sündimisega ei lõpe veel lapse füüsiline kujunemine ja sellesse ilma tulemine ei tähenda sünnituse lõppu. Sellepärast tuli laps "lõpuni teha". Esimestel nädalatel ja kuudel püüti tema keha mitmesuguste võtetega õigeks vormida. Eriti puudutas see enneaegseid lapsi. Üheksa kuu möödumiseni mähiti enneaegselt sündinu lambanahka, hoiti kasuka varruka sees, pandi ahjule sooja või lihtsalt soojendati, et laps "saaks küpseks". Last püüti valmis küpsetada ahjusuudmes leivalabida peal kiigutades (AVM < Jukamenskoje raj, Žuvami k - N. K. Nevostrujeva, s 1919 (1991)). Et laps kasvaks sihvakaks, mähiti ta kõvasti kinni, tehti saunas massaaži ja veniti kergelt käsijalgu. Õigeks peeti ümarat ja siledat peakuju, seetõttu püüti esimestel sünni- 
järgsetel päevadel anda peale õige vorm: saunas leilitatud lapse pea seebitati ja vajutati seda kätega kergelt igast küljest. Usuti, et sagedase saunaskäimise mõjul kasvab laps kiiremini ja füüsiliselt õigesti. Sellepärast köeti esimesel kuul mitu korda nädalas nn lapsesauna (pińjal muńčo).

Saunas võeti harjased - vastsündinu õlgades, seljas, kätes ja jalgades naha all usuti olevat tugevad harjased kočerga või kočurga ('koerakarv'). Tegemist on arvatavasti vene laensõnaga, vene keeles nimetatakse laste harjaseid корчужка, кочеружка. Arvati, et harjased häirivad last, ta magab halvasti ega lama selili. Harjaseid võeti järgmiselt: lapse seljale valati emapiima ja hõõruti see kergete käeliigutustega naha sisse. Mõnikord kasutati piima asemel leivakuule, hapendist või tainast. Seda toimingut korrati, kuni harjased kadusid.

Saunaskäimisel järgiti teatud reegleid, mis imiku puhul olid eriti ranged. Saunas ei tohtinud last kiita, temaga mängida, kutsuda nimepidi ega jätta üksinda, sest muidu ei olevat ravimisest ega pesemisest tolku. Teisest küljest olid need seotud hirmuga, et laps haigestub, et šaitan ('saatan, kurat') või sauna peremees muńčo kuzjo vahetab ta ära. Lapse pesemisega seotud reeglistik ja vahetamishirm osutavad, et sauna tajuti piirina, paigana reaalse ja üleloomuliku maailma vahel, nagu see on tuntud ka teistes traditsioonilistes kultuurides (Šabajev \& Šabajeva 1995: 52). Enamikku lastehaigusi raviti just saunas. Kui laps oli viril ja halvasti magas, peeti parimaks abinõuks haiguse "mahapesemist" või "väljaleilitamist". Sauna raviomadusi tugevdati loitsimisega, last kutsuti vannitama ämmamoor või posija. Mõnikord pesid last vanad naised või lesed, mis võis olla seotud nende rituaalse puhtusega. Seda oletust kinnitab asjaolu, et kuupuhastuse päevadel ei tohtinud naine lapse ravimise ajal saunas viibida. Kui selline naine tuli sauna rinnalapse tavalise pesemise ajal, ei tohtinud ta olla saunas lapsest kõrgemal. Usuti, et nende keeldude rikkumisel võis laps haigestuda, jääda nõrgaks või virilaks (AVM < Jukamenskoje raj, Žuvami k -N. K. Nevostrujeva, s 1919 (1993)). Pärast sauna, eriti pärast ravimist ei olnud soovitav last kiita ega võõrastele näidata. Arvati, et siis pole ravimisest kasu ja last on kerge kaetada.

Laste hooldamisel kasutati traditsioonilisi hügieenivahendeid. Punetama löönud kohad ja nahavoldid kuivatati korralikult ja puistati peale isetehtud lastepuudrit. Selleks kasutati peenestatud kuiva puupuru, läbipraetud jahu, põletatud ja peenestatud karplubjakivi, okaspuude õisikute õietolmu, kuiva tuhka. Punetama löönud kohtadele pandi vati asemel peale kantud rõivastelt noaga kraabitud linakiudu. Punased ja ärritunud kohad määriti taimeõli või rasvaga. Hügieeni järgimist ja lapse hoidmist puhtuses peeti haiguste ennetamise ja tervise hoidmise eeltingimuseks. 


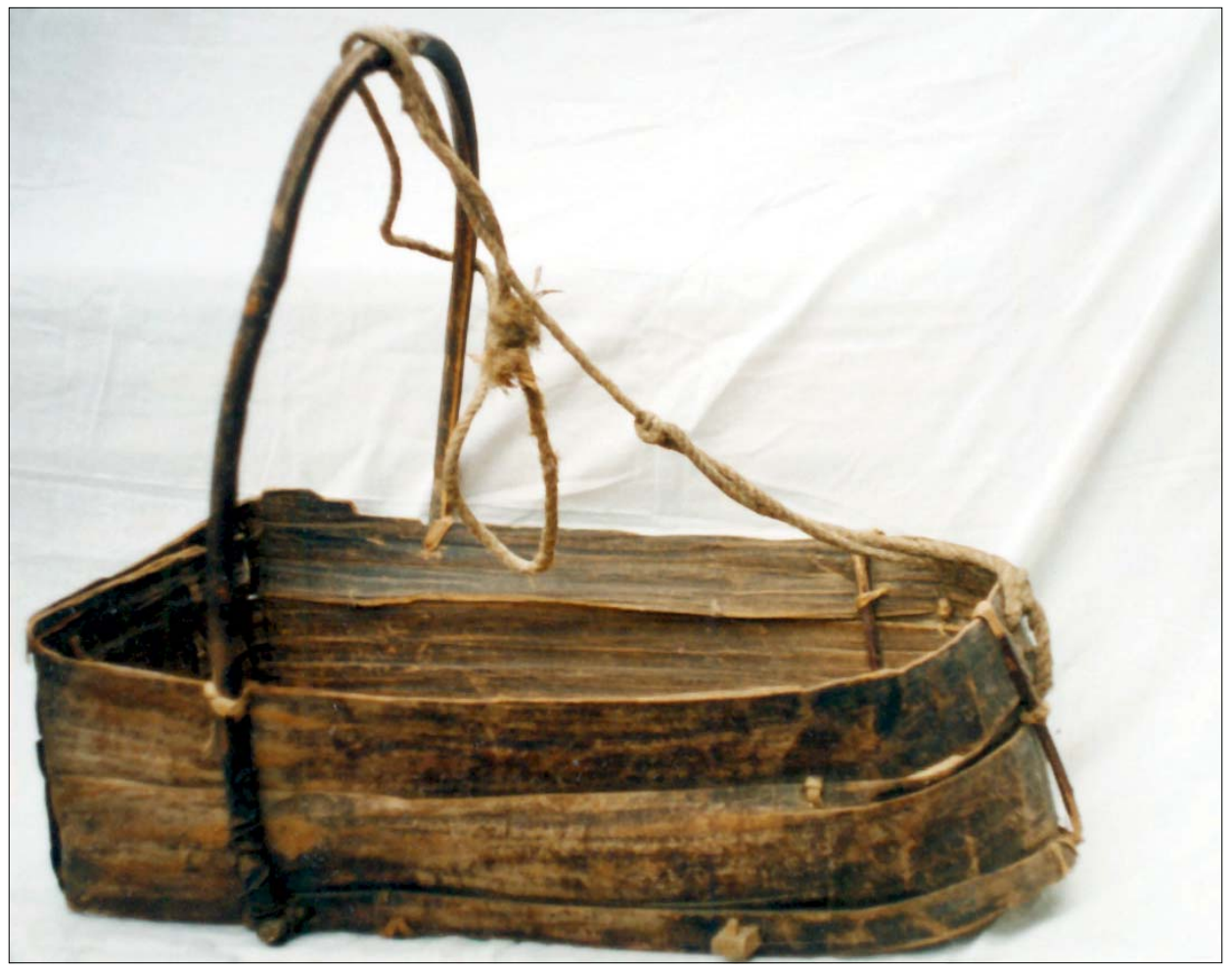

Foto 1. Niinest häll. Glazovi Pedagoogilise Instituudi kogu. Jelena Popova foto.

Esimestel kuudel lamas vastsündinu hällis (kekâ) - 30-40 cm kõrguses niinest kastis, millel oli nöörist või niinest punutud ja laudadega kaetud tugev põhi. Valmistati ka puuraamiga hälle, mille põhi kaeti riidega. Häll seoti pika painduva puu külge, mille teine ots pisteti lakke löödud rõngasse. Kaitsmaks last valguse, putukate ja kaetuse eest varjati häll lina- või sitsikardinaga. Kui tuppa tuli võõras, eriti kaugelt tulnu, varjati häll kiiresti. Hälli kiigutati rütmiliste käeliigutustega või selle põhja külge kinnitatud nööri abil. Tühja hälli kiigutada ei lubatud - kardeti, et lapsel kaob nii uni ära. Äiutades lausuti laulutoonil soove, mõtteid iseenda saatusest ja elust ning lauldi improviseeritud tekstiga laule. Hälliimprovisatsioonide teemadeks olid palve jääda magama, olla kuulekas ja armastada vanemaid. Kiigutamise rütmis ümiseti: $O$-o-o! $E$-e-e!

Lapse voodiriided olid padi (jârultes), tekk (šâbortet) ja mähkmed (t'ebet'). Madratsiks kasutati tavaliselt õlgedega täidetud linakotti. Tähtsad olid amuletid: hällis hoidsid bessermanid nagu udmurdidki kääre, nuga ja raudesemeid (Tšernõhh 1996: 295). Amuletid kaitsesid kaetamise ja majavaimu või 
šaitani poolt äravahetamise eest. Selliseid amulette pannakse lastevooditesse või jalutamise ajaks lapsevankritesse sageli ka tänapäeval.

Tavaliselt hakkasid naised juba esimestel sünnitusjärgsetel päevadel kaasa lööma majapidamistöödes ja võtsid isegi osa põllutöödest kodunt kaugel - põllul või metsas. Et last hooldada ja õigel ajal toita, võttis ema ta kaasa. Lapsi kanti spetsiaalsetes seljahällides ja seljakottides. Imikud näiteks võeti kaasa õlarihmadega varustatud kasetohust ja niinest punutud ja õmmeldud seljahällis (muško). Kaitsmaks putukate, vihma ja päikese eest kaeti häll tihedast linasest kangast eesriidega. Kõige eakamate informantide sõnul oli eesriie kaunistatud spetsiaalse tikandi ja/või aplikatsiooniga. Kas sellel oli kaitsefunktsioon või oli see vaid kaunistus, pole õnnestunud kindlaks teha. Nendel eksemplaridel, mida nägin ekspeditsiooni ajal, ei olnud tikand säilinud. Sageli kasutati eesriideks naisepõlle.

Nâp'jet ehk nâpi õmmeldi tihedast ristkülikukujulisest riidest ja see oli varustatud kahe laia õlarihmaga. Laps pandi sinna istuma ja kanti seljas, kusjuures lapse jalad rippusid külgedel. Psühholoogiliselt tundis laps ennast ema juures hästi, kuid ebakindel pehme iste võis halvasti mõjuda tema luustiku ja selgroo arengule. Sellepärast pandi nâpisse vaid neid lapsi, kes oskasid juba ise istuda ja roomata, sest arvati, et neil on juba keha välja

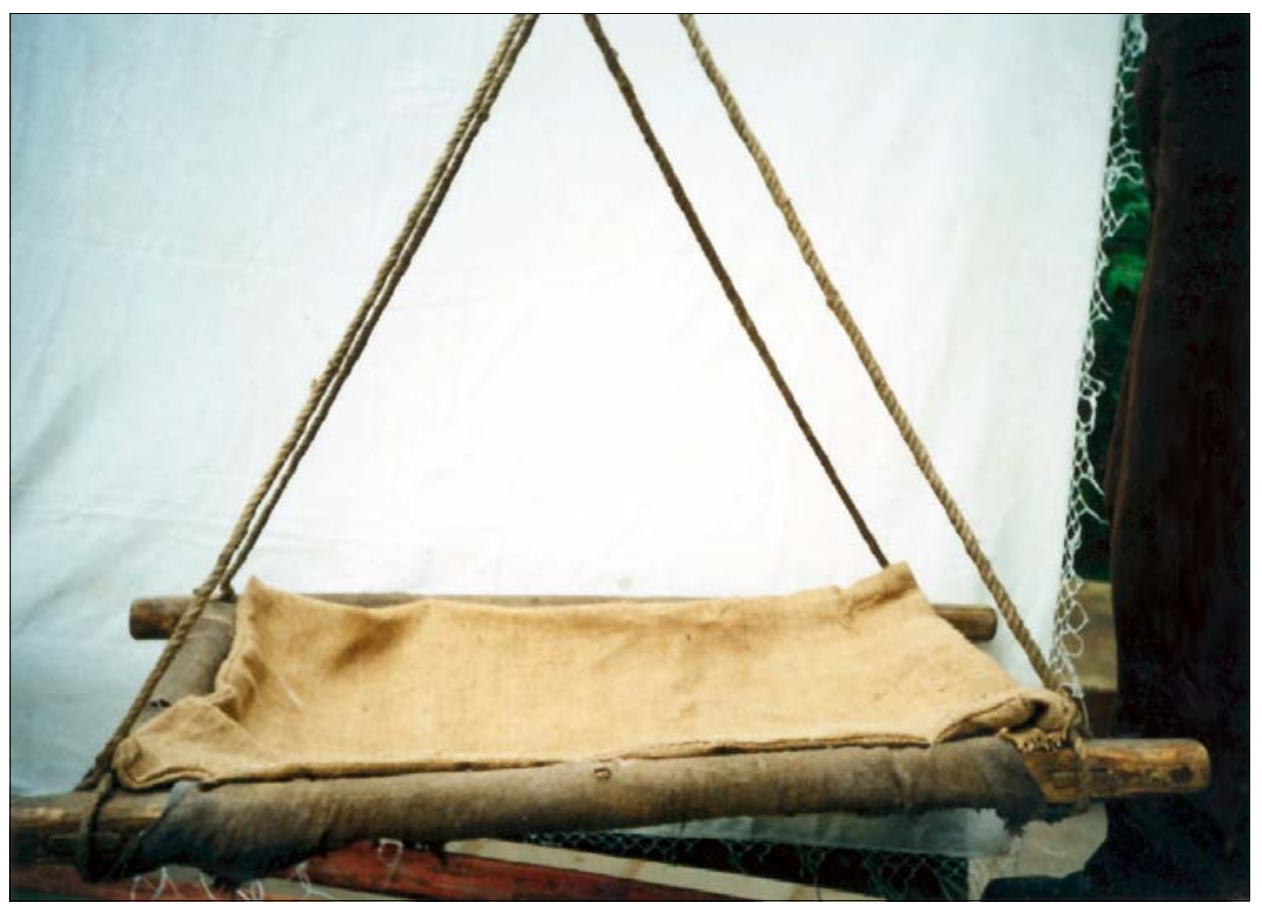

Foto 2. Puuraamiga häll. Glazovi Pedagoogilise Instituudi kogu. Jelena Popova foto. 


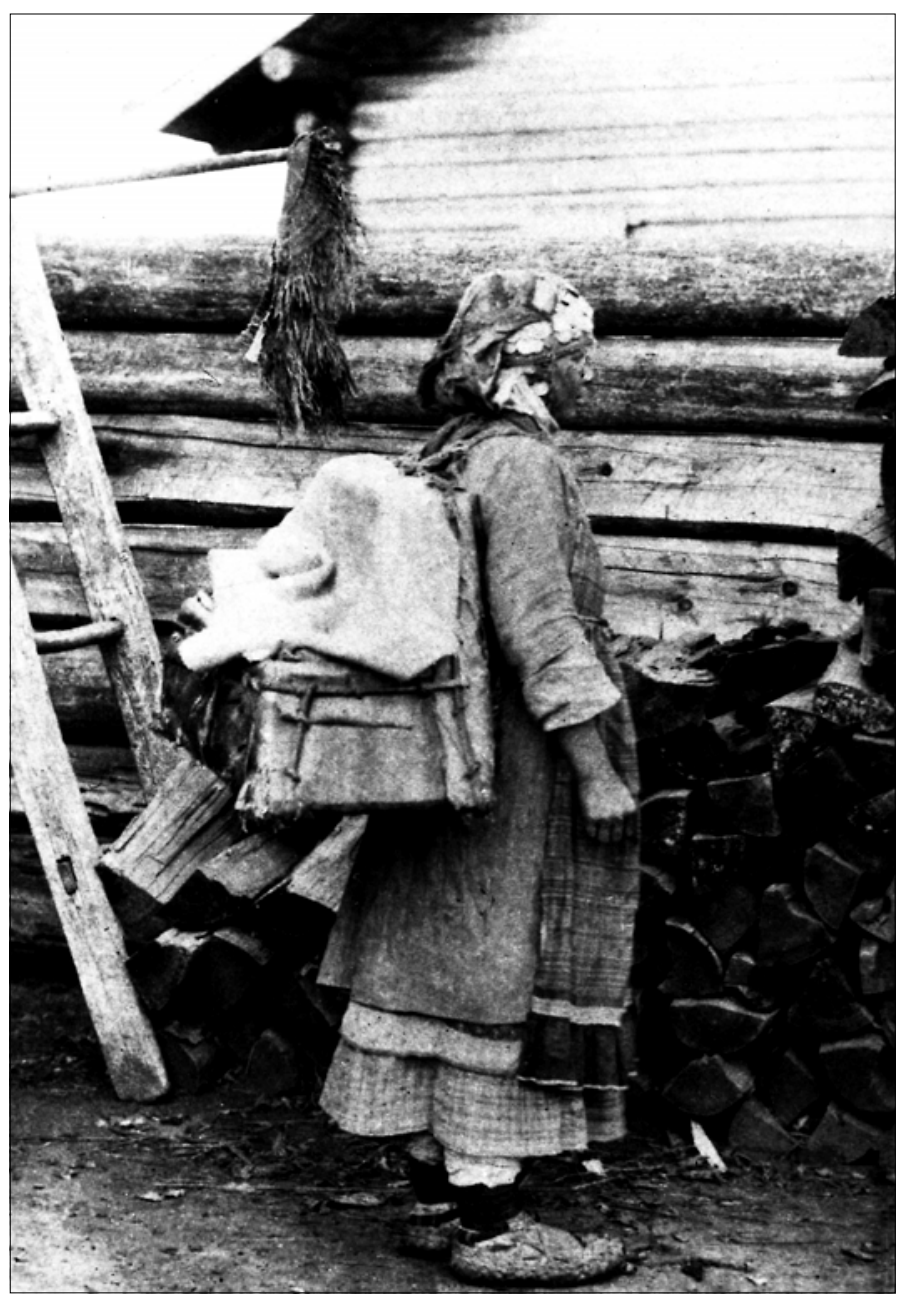

Foto 3. Naine seljahälliga (muško). Glazovi maakond, 20. sajandi algus. Vene Etnograafiamuuseumi (VEM) kogu, nr 354-100.

kujunenud. Analoogne kandmisvahend oli ka udmurtidel, kes kaunistasid selle välimise poole ereda naastpõimekoega. Bessermanide nâpjetil kaunistusi polnud.

Istuma ja roomama hakkavad lapsed pandi istuma erilisse puutüvest õõnestatud tooli (gârkes), millel oli sees põiklaud. Erilist tähelepanu pöörati esimesi samme tegevale lapsele. Lapse käima õpetamiseks kasutati ratastega käimistooli pińjal vel'ton kol'josa ('käimisrattad'): laps hoidis käega rõhtpuust kinni ja lükkas käimistooli enda ees.

Last ei tohtinud hirmutada, kui ta hakkas iseseisvalt seisma või kõndima. Jälgiti, et ta ei kukuks, eriti esimesi samme tehes. Kui ta ikkagi kukkus, ehmus ja nutma hakkas, kasteti kukkumiskohta soolveega, löödi sinna sisse 
nael või sülitati sinna kolm korda. Nõnda püüti kaitsta last kukkumisest tingitud haiguste eest ja hoida ära ehmumisest tingitud käimaõppimistakistusi. Analoogiliselt käitusid ka udmurdid (Vereštšagin: VTAA, f 135, n 2, s 79, L 79). Need bessermanide ja udmurtide toimingud on seotud ettekujutustega, et laps ega täiskasvanu ei kuku juhuslikult, vaid neid "tõmbab koht" ja viib ärevusse haigusevaim $k \partial \partial z ̌$.

Omaette rühma moodustavad lasterõivaste kujundamise, kandmise, hoidmise ja pesemisega seotud keelud ja uskumused. Kahjuks ei ole tänaseni säilinud peaaegu ühtegi bessermani lasterõivaste komplekti. Kuigi paljudes peredes on hästi hoitud traditsioonilisi rõivaid, leidub lasteriiete komplekte haruharva. See on seotud asjaoluga, et neid kandsid mitme põlvkonna lapsed ja need kulusid lihtsalt läbi. Suulist informatsiooni lasterõivaste erijoontest võib vanematelt bessermanidelt veel saada ja säilinud on ka fotosid. Käesolevas artiklis teen lasterõivastest üksnes lühiülevaate, peamiselt seoses laste hooldamise ja amulettidega.

Vastsündinu pesu ja riiete täiskomplekti ei tehtud kuigi varakult valmis. Mähkmeid õmmeldi täiskasvanute kantud rõivastest, tavaliselt särgist naistesärgi alumisest äärest ja meestesärgi seljaosast. Et lapsel oleksid sirged jalad, mähiti ta kõvasti ja seoti spetsiaalse laia nn lastevööga (pińjal kertet). Lastesärke õmmeldi värvimata linasest või puuvillasest kodukootud riidest. Rinnale ja seljale tehti tikand, alläärele ja käistele õmmeldi naastpõimekoest punane äärepael, kumatš (kärtspunane puuvillriie) või värviline sits. Sellisel kaunistusel oli ka kaitsefunktsioon. Poiste ja tüdrukute särkide lõige oli ühesugune, erinevus seisnes vaid pikkuses ja kaunistamises. Tüdrukusärki tavaliselt ei kanditud ja kui laps kasvas suuremaks, õmmeldi sellele rüüšid. Lasteriiete tikkimiseks kasutati omavärvitud odavaid linaseid ja villaseid niite (VEM kogu, nr 111155; 1111-56; 1111-57), samal ajal kui täiskasvanute riideid tikiti alati kvaliteetsete siidniitidega. Nii poisid kui tüdrukud kand-

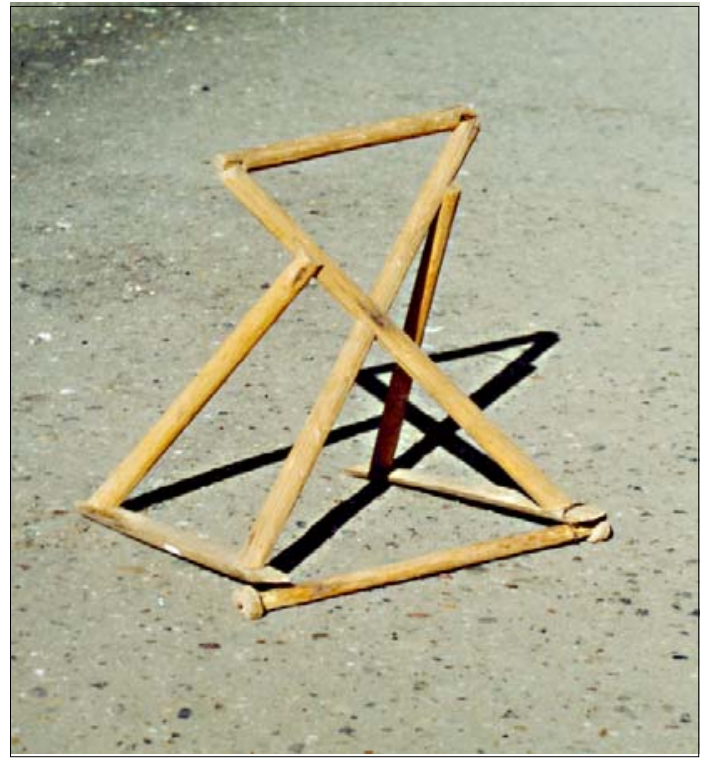

Foto 4. Käimistool. Glazovi rajooni Kuregovo küla. 1993. Glazovi Pedagoogilise Instituudi kogu. Jelena Popova foto. 
sid erilise lõikega linaseid põhjata pükse (pâdestem štan) (VEM kogu, nr 111158). Pükse ei õmmeldud jalgade vahelt kinni, kuni laps õppis oma loomulikke vajadusi iseseisvalt rahuldama. Sellise lõikega lastepükse kasutati veel 1960. aastate keskel.

Laste peakatete, nagu ka teiste riiete juurde kuulusid tingimata kaetusvastased amuletid. Etnograaf Tatjana Krjukova teadaandel pani kaurikarbist ja kitsehabemekrunnist amuletiga mütsi vastsündinule esimest korda pähe ämmaemand. Hiljem, kui sünnitati haiglas, andis sellise mütsi isapoolne vanaema (VEM, 7599-16). Kitsekarvu asendasid mõnikord koerakarvad. Vera Belitser on nentinud, et mütsi laubaosale õmmeldud kaurikarbid olid bessermanidel amuletiks veel 1930. aastatel (Belitser 1947: 190). Rinnalapsele õmmeldi müts tavaliselt peenest kodukootud linast või värvilistest vabrikukanga tükkidest. Amulettideks õmmeldi mütside külge alati metallesemeid, nööpe, pärleid, münte. Ühtaegu amuletiks ja ehteks olid hane sabasuled (udusuled). Hanesuled kuivatati, puistati nendele jahu ja õmmeldi mütsi külge kas ühte ritta või kimbuna kokku. Tänapäeval kasutatakse traditsiooniliselt amulettidena kaurikarpe, udusulgi ja nahatükke peamiselt haige ja nõrga tervisega lapse puhul. Viimastel aastatel kasutatakse amulettidena laialt nööpnõelu, prosse ja rinnamärke.

Vanemate laste mütsid olid keerulisemad. Tüdrukud kandsid umbes neljandast eluaastast teismeliseeani peas piči takjat ('väike takja'). Seda mütsi kirjeldas detailselt kubermangu sekretär ja Vjatka statistikakomisjoni ametnik N. P. Šteinfeld:

Väikesed tüdrukud kannavad tatari meeste tübeteika taolisi ümaraid mütse. Selle äärele õmmeldakse kitsas tress või lihtsalt värviline pael, müts ise tehakse punasest villasest riidest, sellel on paks vooder, see on täiesti ümmargune ja katab tihedalt tüdruku pea. Ette, ühe kõrva juurest teiseni õmmeldakse kaks või kolm rida väikesi hõbemünte (Šteinfeld 1894: 234).

Selline peakate leidub vaid Peterburis Vene Etnograafiamuuseumi kogus ja see kujutab endast kodukootud linavoodriga mütsi, millele laubaosast pealaeni on õmmeldud kaurikarpidest, suurtest portselannööpidest, müntidest ja ümaratest tinaplaatidest kolmnurk (VEM kogu, 1111-54; 6598-3; 7059-7; VEM fotokogu, 1132-13). 1930. aastate lõpul kadus selline peakate kasutuselt. Hilisemad variandid on lõikelt samasugused, kuid rikkalike eheteta. Näiteks 1960. aastatel kasutusel olnud lastemüts tupi ehk tupik meenutas kujult takjat ja seda nimetatigi mõnikord takja, kuid sellel polnud ehteid. Tupi oli ristkülikukujulisest lina- või sitsitükist kuklaõmblusega müts. Mõnikord tupi kooti: poistele mustast, harvemini valgest lõngast, tüdrukutele 


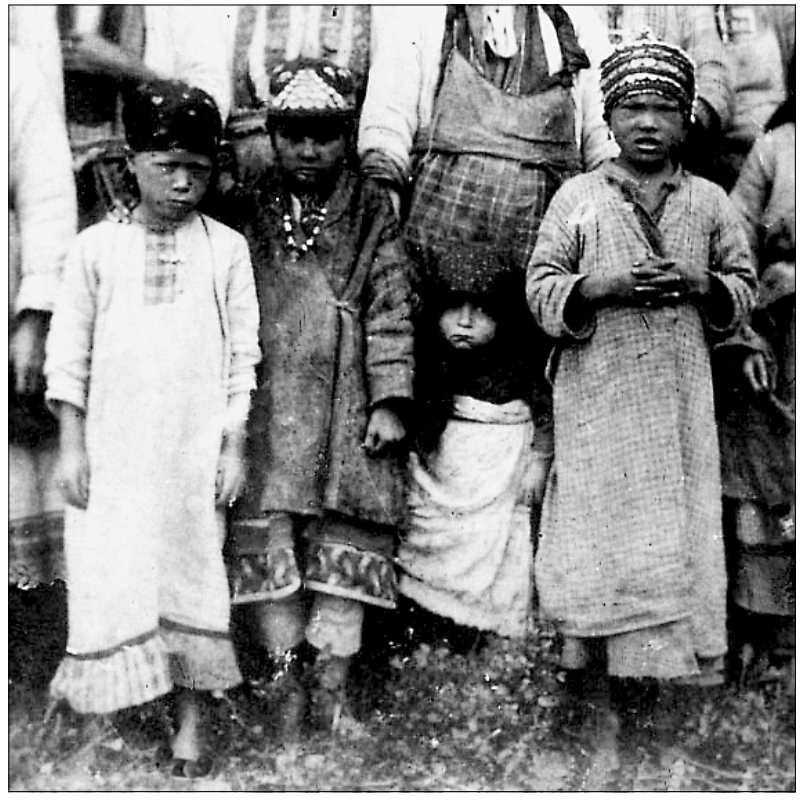

Foto 5. Lapsed Glazovi maakonna Šamardani külas. 1906. Fragment I. K. Zelenovi fotost. VEM fotoarhiiv, nr 1132-14.

aga värvitud lõngast. Tüdrukute peakateteks kasutati laialt eredavärvilisi rätikuid, poistel meestemütsiga sarnanevaid kaabusid.

Riiete ja mähkmete pesemise, kuivatamise ja hoidmisega seotud reeglid moodustavad omaette rühma. Näiteks ei tohtinud loputada imikuriideid allikas ega jões. See keeld oli seotud ettekujutusega, et pärivoolu läheb üks hingedest (urt) ära ja laps jääb kindlasti haigeks (AVM < Jukamenskoje raj, Tõlõsi k - A. N. Baltatšova, s 1937 (1995); AVM < Jukamenskoje raj, Tõlõsi k - Z. I. Baltatšova, s 1929 (1995); AVM < Jukamenskoje raj, Žuvami k I. K. Malõhh, s 1906 (1993)), samuti usuga, et pesemisel võivad haigused sattuda jõeveest lapse rõivastesse. Pestes ei tohtinud lasteasju pahupidi pöörata, aia taha riputada ega ööseks õue jätta - siis minevat kurjad olendid ja haigusevaimud neisse. Arvati, et õues elavad kurjad vaimud, kes on eriti aktiivsed öösiti, mistõttu ööd peeti ohtlikuks ajaks. Sellised olendid jõudsid lapseni rõivaste kaudu. Keeldu loputada imikurõivaid voolavas vees ja riputada aia taha järgitakse mõnedes peredes praegugi.

Igapäevaelus järgiti reegleid, mille rikkumine võis mõjuda lapse iseloomule, käitumisele ja saatusele. Näiteks oli keelatud mängu ajal panna pähe toidunõusid, eriti sõela, sest arvati, et siis jääb laps lühikeseks. Imikule ei tohtinud näidata peeglit - siis kaotavat ta une. Lapsel ei lubatud vaadata 
tulle - hakkavat voodit märgama. Kehtisid ka toidukeelud: lapsed ei tohtinud süüa jäärapead - eksivat tulevikus metsas - ning liigne munakollase söömine muutvat naha kollaseks.

Imiku põhitoiduks oli rinnapiim, kuid spetsiaalset toitmisrežiimi ei olnud, last toideti siis, kui ta oli näljane või nuttis. Rinnapiimaga toideti last kahekolme aastani või järgmise lapse sündimiseni. Naised olid sageli tööl põllul või metsas, sellepärast oli lapse regulaarne toitmine raske ja talle hakati varakult andma lisatoitu. Teisest-kolmandast nädalast alates anti talle lutsida riidenuts, kuhu oli pandud piima või koorde kastetud mälutud leib mee või suhkruga. Seda nimetati leivalutiks (ńjań sosok) või kaltsulutt (basma sosok). Hiljem anti lahjendatud lehmapiima. Neljandast-viiendast elukuust hakati lapsele söötma täiskasvanute toitu: putru, mälutud liha, keedetud ja riivitud juurvilju. Hiljem kasutusse võetud kummilutid olid vanemate naiste hinnangul imikule kahjulikud, sest nende imemisel kujunevat suuõõs valesti.

Rinnapiima puudumist peeti lapse tervise halvenemise, normaalse arengu ja kasvu aeglustumise üheks põhjuseks. Rinnapiima kadumist seostati tavaliselt rinnahaiguse ja kaetusega. Sellepärast polnud soovitav hoobelda piima rohkusega ja imetada last võõraste juuresolekul. Toitva ema rinnahaigust seostasid bessermanid alati esivanemate mõjuga (Zelenin 1916: 43). Rinnapiima kadumist seletati veel majahaldja halva suhtumisega naisesse. Sellisel juhul ohverdati majahaldjale leiba ja võid. Rinnalastega naised olid üksteise lastele ammeks, kui kellelgi piim kadus või seda ei jätkunud.

Tähtsad sündmused lapse elus olid esimese hamba ilmumine, esimesed sammud, esimene juukselõikus ja majast väljumine. Neid peeti üsna riskantseteks hetkedeks ja usuti, et neist sõltub lapse edasine areng, sellepärast kaasnesid nende sündmustega keerulised rituaalid, mis on tänini üsna hästi säilinud laste hooldamisega seotud keeldudes ja reeglites.

Esimese hamba ilmumist tähistati kingitusega. Hammast märganud inimest nimetati hambaleidjaks (piń šedtiś). Ta kinkis lapsele särgi või lusika ja sai ka ise lapse emalt väikse kingituse või kosti. Kingitusi vahetati selleks, et lapsel tuleksid hambad kiiremini ja oleksid tugevad. Spetsiaalsed toimingud sooritati kukkunud piimahambaga (nonem piń ehk jâl piń). Laps pani selle kaltsu või leivatüki sisse ja viskas üle õla katusele või peitis seinaprakku. Mõnikord visati hammas koerakuuti või ahju alla hiirele ja paluti neil anda äratulnud hamba asemele uus ja tugevam. Lema ja Lekma ülemjooksu (Ježovo, Šamardani, Ježovski Potšinoki ja Ust-Lemi küla) bessermanide arvates ei tohtinud visata piimahammast loomadele, siis olevat laps teistega tülis nagu kass koeraga ning tulevikus võivat tema lapsed olla inetud või füüsilise puudega. Sellepärast peideti nendes külades piimahammas üksnes elumaja või majapidamishoone seinaprakku, et see ei satuks kassi ega 
koerale kätte (AVM < Jukamenskoje raj, Ježovo k - T. I. Volkova, s 1924 (1996).

Aastaseks saanud lapsel lõigati esimest korda juukseid. Neid ei tohtinud visata õue, sest arvati, et siis viib lind need oma pessa, lapsel tekivad peavalud ja ta jääb rumalaks. Tavaliselt hoiti lõigatud juuksed alles või põletati ära nagu järgmiste lõikamiste korralgi.

Imikuga välja minnes tehti tema laubale jahu või tahmaga kaetusevastane märk. Vastutulijatel ei lubatud last kiita, teda silmitseda ega rääkida lapse tervisest. Last kiitnud inimene pidi kolm korda sülitama ja ütlema: Ärgu vaid kaetagu!; Ärgu tulgu minust kaetus! Nõnda tegid ka kõik, kes tulid nurganaist ja vastsündinut vaatama.

Paljud haiguste ravimise ja profülaktikaga, aga ka lapse tähtsamate elusündmustega seotud rituaalid sooritati kodus ja need olid perekonnakombestiku osad. Raskete lastehaiguste ravimisega tegelesid ämmaemandad ja posijad, kes kasutasid rikast rahvatraditsiooni ratsionaalsete ja maagiliste võtete kompleksi. Eriti puudutas see keerukaid teadmisi haiguste mütoloogiliste põhjuste kohta ja traditsioonilisi uskumusi. Enamiku profülaktiliste ja ravirituaalide eesmärk oli lapse tervise säilitamine ja haigusevaimu väljaajamine. Usuti, et lapse saatuse ja tervise üle valitseb kõrgeim jumal inmar ning tema tahtest sõltub, kas haige saab terveks või mitte. Kui laps peab tervenema, saab ta igal juhul terveks, kui mitte, siis sureb vaatamata kõikidele ravimiskatsetele. Võimalik, et sellepärast öeldigi: Inmar võttis lapse tagasi!; Inmar andis lapse, inmar võttis!, Inmar ei lubanud lapsel selles ilmas elada! See ei tähenda, et vanemad ja lähedased ei võidelnud lapse elu eest.

Rahvameditsiinis on tähtsal kohal ettekujutused emakoogist ehk platsentast kui inimese kaitsjast. Pärast sünnitust pesti platsenta korralikult üle, mähiti valge lina sisse ja maeti keldris vana viisu sees maha. Kui platsenta rahu oli häiritud või matmiskohal oli prahti, peeti seda haiguse põhjuseks. Usuti ka, et lohakalt või valesti maetud platsenta teeb lapse rahutuks ja põhjustab halbu unenägusid. Silmahaigusi ja mõningaid nahahaigusi seostati samuti platsentaga. Kui haigust seostati platsentaga või arvati, et tervenemine sõltub üksnes platsentast, ohverdati platsentale keldris matmiskohas sulavõid. Sellest kohast pühiti praht ära ja valati sinna sulavõid. Platsenta poole pöördumisel paluti tervenemist ja meenutati, et ta peab last kaitsma ja tema eest hoolitsema. Tänapäeval sünnitatakse haiglas ja platsentat ei maeta keldrisse, kuid usutakse, et väikelastele võivad mõjuda samas majas varem sünnitatud laste keldrisse maetud platsentad.

Traditsioonilised ravivõtted ja ennetusabinõud olid seotud ettekujutustega haiguse põhjustest. Haigused jagati kaheks: sisehaigusteks (ket puš 
viśjon) ja südamehaigusteks (sjulem viśjon). Sisehaigusi seletati kaetuse ja nõidusega, aga südamehaiguse saatsid inimesele surnud esivanemad (UAKKI arhiiv, n 2N, s 391, L 106). Teisest küljest arvati, et kõik haigused peale põrutuste ja lõikehaavade on haigusevaimude (luljos) saadetud, kes nõuavad ohverdamist (UAKKI arhiiv, n 2N, s 391, L 100). Tõkestamaks haiguse majja sisenemist pandi läve alla amuletid. Tavaliselt olid need lõikavad esemed, nt nuga, kirves, vikat, sirp. Usuti, et hirmust end terava esemega vigastada ei tule haigus tuppa (AVM < Jukamenskoje raj, Žuvami k - I. K. Malõhh, s 1906 (1993)). Epideemiate puhul käidi ikooniga ümber maja, künti küla ümber maa üles ja tehti möödasõitjatele ringtee. Kardeti, et mõni haige läheb läbi küla ja jätab haiguse tänavale, pärast tuleb haigus tuppa (UAKKI arhiiv, n 2N, s 391, L 102; AVM < Jukamenskoje raj, Žuvami k - K. A. Nevostrujeva, s 1924 (1991); AVM < Jukamenskoje raj, Šamardani k - K. I. Karavajeva, s 1915 (1991)). Õuest toodud haigus tabab eeskätt nõrgimat pereliiget - last. Selle ettekujutusega on seotud reegel, et kaugelt tulles puudutati kõigepealt ahju ja alles siis mindi tuppa, kus oli laps. Selline komme oli levinud ka udmurtidel (Vladõkina 1992: 134).

Kui majas oli haige laps, järgiti teatud kodutööde keelde ja peeti kinni käitumisreeglitest, et haigusvaimu mitte vihale ajada ega last kahjustada. Näiteks ei loputatud lapse riideid voolavas vees, et hing (urt) ei läheks pärivoolu ära. Ei tohtinud leotada pesu leelises, puhastada korstnaid, pühkida tuhka, koristada. Pereliikmed ei tohtinud tülitseda, sõimelda ega loomi lüüa. Kui majas oli haige, oli keelatud ka loomi ja linde tappa. Usuti, et nende keeldude rikkumine võib haigusvaimu vihastada ja see võib omakorda aeglustada tervenemist ning tuua kaasa haige surma.

Haigusvaimu, palavikku ja igat haigust, millega kaasnes palavik, nimetati per või viśjon pâr. Nii nimetasid haigust ka udmurdid, Grigori Vereštšagini sõnul nimetati nõnda soetõbe või palavikku (Vereštšagin: VTAA, f 135, n 2, s 79, L 47). Ettekujutuste järgi tuli haigusevaime kostitada ja suhtuda nendesse lugupidamisega. Ainult siis võivat nad lahkuda "vabatahtlikult" ja inimene saab terveks. Mõnikord võis haigus hüljata lapse tema tervenemist ootamata, siis seletati rasket haigust või tüsistust sellega, et isegi haigusevaim per on inimese hüljanud. Usuti, et per võib lahkuda koos külaliste või pereliikmetega, sellepärast ei toodud last nendega hüvasti jätma ega lubatud neid lapse juurde; last ei viidud akna ega ukse juurde. Kohustuslike tabude järgimine ja külalislahkus haigusvaimu vastu tagas haiguse kerge kulgemise ja kiire tervenemise.

Kui halvenemise põhjuseks peeti peri lahkumist enne haige tervistumist, viidi läbi rituaal nimega per jârbârjtan ('ohverdamine perile') või per konojaton ('peri kostitamine'). Rituaali nimetati ka per kono ('peri vastuvõtt'). 
Peamine oli, et haigusvaimuga käituti kui tähtsa külalisega, keda kostitati etiketi kohaselt. Rituaali viis läbi naisravitseja, mõnikord ka lihtsalt vanem naine, kuid kindlasti pidi ta olema hea rituaalitundja. Arvati, et iga ebatäpsus võib põhjustada lapse tervise halvenemist, sest per võib kutsest keelduda ja jätta tagasi tulemata. Rituaali varaseim kirjapanek leidub Yrjö Wichmanni bessermani keelenäidetes. Ta on kirjutanud üles palve, mida lausuti värava taga, valge laudlina, leib ja või kaasas. Naisravitseja kummardas kolm korda erinevas suunas ja pöördus haiguste poole sõnadega:

Ärge pahandage! Ärge solvuge! Tulge, tulge, kallid külalised! Miks solvusite meie peale? Ärge pahandage! Me valmistasime teile head kosti! Tulge heaga meile! Võib-olla me karjusime ja tülitsesime? Ehk riidlesime koeraga? Ehk riidlesime kassiga? Ärge pahandage! Tulge, tulge, külalised! Hakkame koos elama! Andke Vassilile [siin lapse nimi - J.P.] tagasi tervis ja hea enesetunne! (Wichmann 1893: 168).

Välitööde materjalid osutavad, et kindlat kutseteksti polnud. Improviseeritud kutses loetleti tavaliselt põhjusi, mis võisid olla haigusevaimu pahandanud - tüli pereliikmete vahel, töökeeldude rikkumine, koduloomade solvamine jm. Kutse sisaldas palvet tulla ja andestada keeldude rikkumine. Näiteks toon veel ühe teksti, mille panin kirja 1991. aasta välitöödel:

Meie lapse per läks ära! Ta läks, kui loputati riideid. Nii me anname peri tagasi! Me tülitsesime kodus, kuid sa ära pahanda! Toogu sinu tagasitulek talle [lapsele - J.P.] paranemist-tervekssaamist! Saagu meie laps terveks! Söögu ja joogu ta jälle! (AVM < Jukamenskoje raj, Žuvami k - N. K. Nevostrujeva, s 1919 (1991).

Haigusvaimu kutsunud, tuli naine tagasi tuppa, kuid jättis väravad ja uksed lahti, et vaim saaks sisse tulla. Mõnikord viidi rituaal läbi toas avatud ukse ees. Laudlina, millel olid rituaali ajal leib ja või, pandi haige lapse kõrvale. Siis kutsuti per taas laua äärde ja pere hakkas sööma. Kindlasti oli keedetud lihapuljongiga odrajahuputru või herne-kruubiputru. Lauas oli vaikne, sest inimestega koos arvati söövat ja kosti võtvat ka per. Pereliikmed ei tohtinud rituaali ja söömise ajal majast väljuda ega võõrad siseneda, muidu lahkuvat per uuesti. Haige täieliku tervenemiseni oli keelatud mustade, poriste ja mürarikaste tööde tegemine, toidu ja asjade laenamine ning võõraste lähenemine lapsele. Kõiki ettevaatusabinõusid põhjendati sellega, et per võib taas solvuda ja lahkuda. Neid kombeid järgitakse mõnedes peredes laste raske haiguse ajal tänapäevalgi.

Laste ja täiskasvanute haigustega oli seotud varem üsna levinud ettekujutus, et haigusvaime tuleb toita, võtta vastu ja ära saata kui kalleid külalisi. 
Usuti, et just toitu otsides "haaravad" nad inimestest kinni. Nikolai Nikolski kirjeldas, et bessermanid panid aknale kausi erinevat sorti küpsetiste ja võiga, kostitamaks haigust ja panemaks teda halastama (Nikolski 1919: 77). Tulles soetõbise majja, võeti haiguse toitmiseks kaasa leivakannikas, et haigus ei tuleks pärast kaasa (UAKKI arhiiv, n 2N, s 391, L 102). Leetrite (pužâ) ja rõugete (čača) puhul hoiti valge linaga laual sulavõi ja sool, et haigus ei oleks näljane ega "sööks" haiget. Väljapoole küla või külaväravate juurde pandi kolmeks lõhestatud oks pannkookide, pudru ja riideribadega (Nikolski 1919: 78). Udmurdid viisid sellise oksa küla servale epideemiate ajal (Vladõkin 1994: 136).

Bessermanid uskusid, et surnud mõjutavad elavate, sh laste tervist. Unetust, mõningaid psüühilisi haigusi ja laste virilust seletati esivanemate vihaga. Lapse unetuse korral ohverdati riidetüki sisse pandud kruupe, jahu, soola ja väikesi münte, mis viidi talu piiridest välja. Võis piirduda ka ühe esemega, kuid kindlasti mähiti see riide sisse ja visati põhja suunas sõnadega:

Und, magusat und andku [esivanemad - J.P.]. Andku magusat ja kerget öist und (AVM < Jukamenskoje raj, Ježovo k - T. I. Antuganova, s 1924 (1996).

Lapse pika ja raske haiguse korral paluti vanal naisel viia ohverdamine läbi erilises palvekojas kualas (vej kiśkan 'või valamise koht', vej kiśkan kuala 'või valamise $k u a l a$ '). Kohustuslik ohvriand oli sulavõi, mis valati muldpõrandale või väiksesse tassi. Naine palus esivanematelt lapsele tervist (UAKKI arhiiv, n 2N, s 391, L 72). Selliseid ehitisi oli külas sama palju kui suguvõsasid, kuid ohverdama mindi vaid enda omasse. 1960. aastate lõpust saadik ei korraldatud neis enam kollektiivseid palvetamisi ja kualad lagunesid pikapeale. Hiljem kandusid sakraalsed funktsioonid üle nende endistele asukohtadele. Mõnedes külades on selline ala aiaga piiratud, teistes puudesse ja põõsastesse kasvanud. Tänapäeval ohverdatakse seal raskete esivanematelt või kualast tulenevate lastehaiguste puhul võid.

Lapse psüühiline ja füüsiline tervis oli tingitud ka tema hingeseisundist. Bessermanide ettekujutuste kohaselt oli inimesel kaks hinge - lâl ja urt. Haiglaslikku olekut ja psüühikahäiret seletati urti lahkumisega haiguse või ehmatamise tõttu - seda juhtus sagedamini just lastel. Urti lahkumine oli nii haiguse põhjuseks kui ka tagajärjeks ning sellele võis järgneda surm, kui hing ei tulnudki tagasi. Kui teine hing lăl lahkus inimese kehast, saabus rahvauskumuste kohaselt kindlasti surm, sest seda hinge tavaliselt tagasi saada ei õnnestunud. Uurimused näitavad, et rahvameditsiinis oli urti tagasitoomine laialt levinud, kuid sellega tegelesid vaid kogenud posijad. 
Urti tagastamise rituaal kandis nime urt et'jon ('urti kutsumine'). Naisposija läks värava taha valge laudlina või rätikuga, kaasas leib, sool, või ja haige rõivad (et hing leiaks lapse riiete järgi). Ta otsis hinge aiast, värava tagant, saunast ja teiste hoonete juurest, kummardas ja palus urti tulla tagasi lapse juurde. Taluhoonete ja värava tagune ala oli piir "oma" ja "võõra" vahel, kuhu hing võiski minna. Posija tõi tuppa rohtu, prahti ja pilpaid, arvates, et koos nendega tuleb urt tagasi. Toodud esemed ja lapse riided pandi lapse voodi kõrvale, lina aga laua kõrvale. Pereliikmed kummardasid kolm korda lina suunas, kutsudes nõnda urti maitsma lauale aukohale pandud leiba, võid ja teed. Pere istus laua taha alles pärast kummardusi ja urti sööma kutsumist (UAKKI arhiiv, n 2N, s 391, L 106-108). Rituaalil oli lokaalseid erijooni: Gordino küla bessermanid keetsid odrajahuputru jäära või lamba küljeluudest valmistatud puljongis. Seletati, et urt elab inimese sees roiete vahel.

Kirjeldatud rituaaliga on seotud ehmatuse ravimine. Nagu juba öeldud, võis ehmatus olla urti lahkumise põhjus. Kui laps ehmus loomast või linnust, suitsutati teda vastava looma karvade või linnu sulgedega. Linnust ehmunud last vannitati vees, millesse oli segatud suletuhka ja ämblikuniiti. Seda tehti kindlasti keset tuba ematala all. Kui koerast ehmunud last ei onnestunud ravida tavalisel viisil, nimetati seda koerahaiguseks (pânô kâl) ja "küpsetati" last ahjus. Haige pandi istuma panni või labida peale ja öeldi teda ahjusuu ees hoides:

Ma pistan ta [lapse - J.P] ahju. Mingu koeraehmatus, mingu kassiehmatus mööda. Mingu ehmatus mööda ja mingu haigus suitsulõõrist välja (AVM < Jukamenskoje raj, Žuvami k - I. K. Malõhh, s 1906 (1993)).

Raskete lastehaiguste hulka arvati kaetusviis pož kijon-pâdon śjudemân ('räpaste käte-jalgadega toidetu'). Haigestumist seletati sellega, et lapsesse puututi pärast suguakti pesemata kätega ning selle tulemusena muutus laps kahvatuks, nõrgaks ja kõhnaks. Haigus võis lõppeda surmaga, kuid isegi siis, kui haige tervenes, jäi ta nõrgaks ja oli tihti haige. Last võis nakatada ka paljude naistega vahekorras olnud mees. Sellist meest ei lubatud väikelapse juurde ega antud last tema sülle. Bessermanide ettekujutused inimese "mittepuhtusest" pärast suguühet on analoogilised komide ettekujutustega pežist kui eriomadusest, mis tekib pärast seksuaalvahekorda, on kahjulik inimestele, nakatab teisi (eriti lapsi) ja kandub edasi puudutuste kaudu (Nalimov 1991: 6, 18). Bessermanid pidasid seda haigust ravimatuks ja viisid sellepärast sünnitust imiteerides läbi uue lapse "saamise" ehk "sündimise" rituaali. Rituaal viidi läbi saunas. Naine pidi imiteerima tegeliku sünni- 
tusega sarnast piinlemist ja posija ulatas lapse kolm korda tema jalgade vahelt läbi. Samal ajal nad vestlesid. Posija küsis "sünnitajalt", millise lapse too sünnitab. Ema pidi vastama olenevalt haige lapse soost, et poisi või tüdruku. Lapsele anti ka uus nimi. Veel 1950. aastatel võis kohata bessermanide hulgas kahe nimega inimesi. Teine nimi oli küll mitteametlik ja dokumentidesse seda ei kirjutatud, kuid tavaliselt tundis külarahvas inimest just mitteametliku nime järgi. Praegu mäletavad seda kommet vaid lapsi ravivad posijad ja rituaalis osalevad eakad naised. Informandid ütlesid, et kahe viimase aastakümne jooksul on seda rituaali harva korraldatud ja paljud, kes ei ole sellest haigusest teadlikud, ravivad seda kui kaetust või nõidust. Aga kui rituaal korraldataksegi, antakse ravitavale teine nimi üksnes formaalselt ja edaspidi seda ei kasutata.

Levinumate lastehaiguste hulka arvati kaetus (siń uśjon): laps nuttis sageli, ei jäänud magama ja muutus rahutuks. Lapse kaitsmiseks kasutati amulette, mis kinnitati peakatetele, särgirinnale, kaela või randmele. Näiteks seoti kaela raudese, kadakakiust või vastupäeva keritud niit; käel kanti punast lõnga või niiti. Erinevad raviviisid seisnesid kaetuse "mahapesemises", "väljaleilitamises" ja "põletamises". Lapse nägu pesti veega, millega olid eelnevalt pestud ukselink ja lauanurgad. Spetsiaalselt kaetuse ravimiseks kasutati enne päikesetõusu majja toodud allikavett. Raviomadused omistati suurel neljapäeval toodud veele ja suvalisel neljapäeval hommikuse või õhtuse hämariku ajal kolmest allikast võetud veele. Veenõusse pandi raudese, see kaeti kaane või käterätiga, et kurjad vaimud ega šaitan seda teel koju ei rikuks. Ravimiseks mõeldud vett hoiti alati kaetuna ja akendest-ustest eemal. Paljude rahvaste mütoloogilistes ettekujutustes vaadeldakse aknaid ja uksi välisilma piirina, millel on eriti ohtlike kohtade staatus ja järelikult eriline semantiline pinge (Baiburin 1983: 135). Bessermanidel arvates olid aknad ja uksed peamised kohad, kust sisenesid haigused ja šaitan, seetõttu hoiti vett pingi all, köögis või pühasenurgas ikooni taga. Enne ravimist soojendati seda veidi, kuid ei lastud keema - siis võis vesi kaotada tervistavad omadused. Vee raviomadusi suurendati tüübilt sarnaste posimistega, mis koosnesid mitmest kaetuse hävitamise lühipalvest. Üks näide:

Vesi võtku kaetus ja nõidus ära! Võtku kollased ja rohelised sellelt, kes kaetas! Tehku see ta terveks! (AVM < Jukamenskoje raj, Žuvami $\mathrm{k}$ - F. I. Nevostrujeva, s 1907 (1993)).

Raviefekti suurendamiseks pesti lapse nägu keset tuba ematala all.

Kaetust raviti ka jaanipäeva hommikul korjatud kastega. Haigete lastega peredes hoiti see vesi aasta läbi alles. Kaste korjamiseks laotati rohule 
käterätik või riie ja kui see kogus endasse piisavalt kastemärga, väänati kaste nõusse.

Kaetuse ravimisel kasutati ka tuld, mis pidi "põletama ära" haiguse põhjustanud silmad. Laps pandi istuma ematala alla ja tehti tema pea ümber näpuotsatäie soolaga kolm ringi. Seejärel visati sool tulle ja öeldi:

Põletagu tema [kaetaja - J.P.] silmad ära! Olgu see meie lapsele terviseks! Põletagu tuli kaetus! (AVM < Jukamenskoje raj, Žuvami k N. S. Malõhh, s 1918) (1993)).

Väga levinud uskumuste kohaselt olid mütoloogilistest olenditest lapsele ohtlikud saunahaldjas (munčo kuzjo), metshaldjas (čašša kuzjo) ja majahaldjas (korka kuzjo), kes võisid nii haigusi põhjustada kui ka aidata kaasa tervenemisele. Autori välitööd osutavad, et viimastelgi aastatel on need ettekujutused olnud üsna püsikindlad nii rahvameditsiinis kui ka igapäevaelus.

Suurt muret võis perele tekitada majahaldjas, kes ei võtnud vastsündinut omaks. See võis juhtuda siis, kui majas ei olnud ammu lapsi olnud ja lapse sündi võeti võõra inimese sissetungimisena. Kas varem esitleti majahaldjale vastsündinut spetsiaalse rituaaliga, ei õnnestunud välja selgitada, kuid veel 20. sajandi alguses ohverdati lapse sündimise puhul korka kuzjole: majahaldjale pandi ohvriand keldrisse improviseeritud lauale - see oli palkide vahele pistetud väike valge riidega kaetud pilbas. Pilbas oli lauaks ja riie linaks, millele asetati võileib (UAKKI arhiiv, n 2N, s 391, L 108), mõnikord ka putru või munapannkook. Ühe ekspeditsiooni ajal õnnestus mul näha kaasaegset rituaali, milles esitleti last majahaldjale: pärast haiglast tulekut toodi laps keldri sissepääsu juurde ja pöörduti last kätel kiigutades korka kuzjo poole palvega last mitte solvata. Seejärel öeldi lapse nimi ja esitleti teda kui uut pereliiget, kes hakkab majas elama.

Kui arvati, et majavaim ikkagi hirmutab last, viidi keldrisse valgel linal võileib ja pandi see maja lõunapoolses osas muldrile. Nõnda tehti ka raskete lastehaiguste puhul, kui taheti korka kuzjo abi. Kui terve laps muutus virilaks ja hakkas kõhnuma, arvati, et korka kuzjo vaevab teda või on vahetanud terve lapse oma lapse vastu. Saamaks õige laps tagasi, jäeti keldrisse ööseks lapse särk ja hommikul pandi see lapse voodi kõrvale. Teistel juhtudel viis naisposija lapse keldrisse ja palus majahaldjal õige laps tagasi anda. Sarnane komme oli tuntud ka udmurtidel (Maksimov 1925: 88).

Gordino küla bessermanid sooritasid aga uue lapse saamise rituaali nii: last vannitati keldris jõeveega ja posija ulatas ta läbi rangide ema kätte. See komme sümboliseeris uue lapse sündimist endises väärtuses. Nõnda ei hävitatud üksnes sümboolselt haigust, vaid saadi tagasi ka laps. Selline komme on erineval kujul tuntud paljudel rahvastel ja sümboliseeris taassün- 


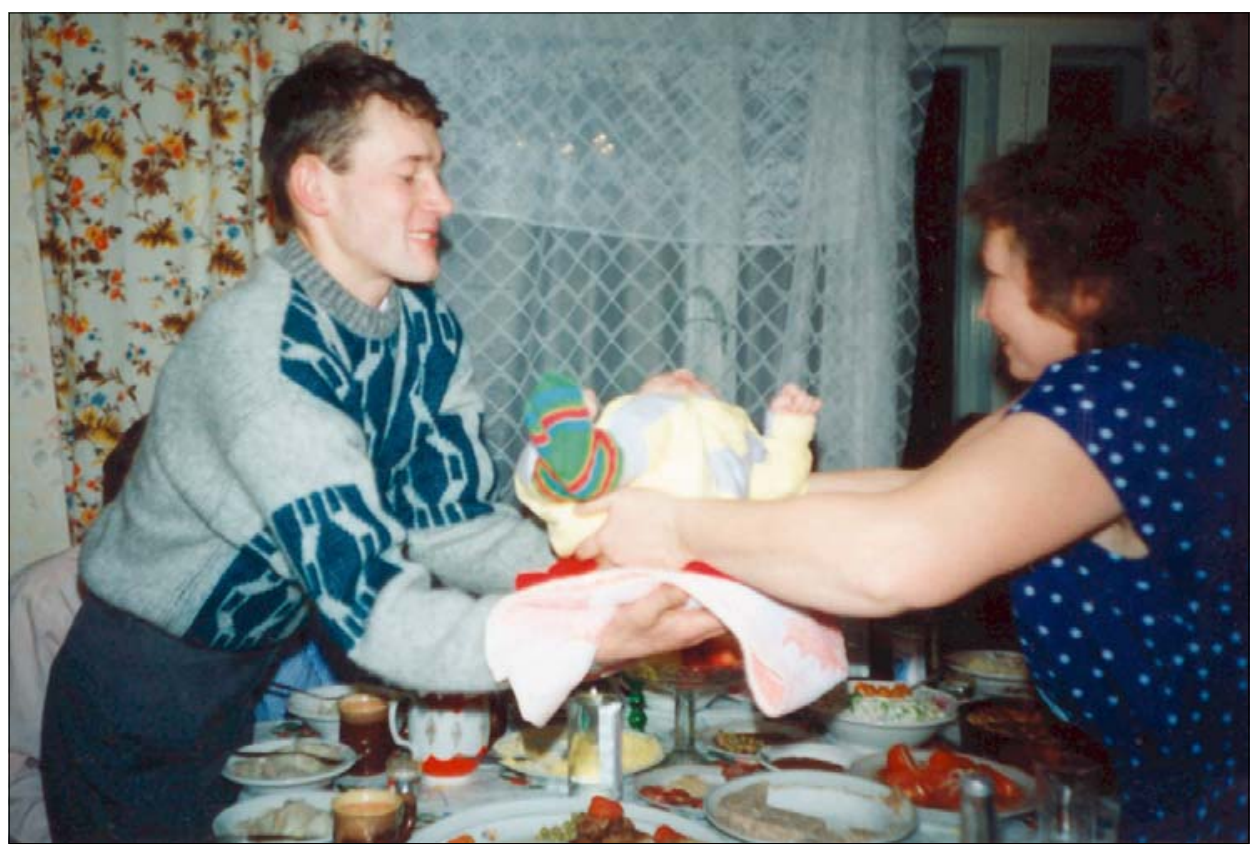

Foto 6. Lapse kodune ristimine. Glazovi linn. 1996. Jelena Popova foto.

dimist, rangid täitsid sünnitamisorgani funktsiooni (Iljina \& Šabajev 1985: 118).

Lapsele peeti väga ohtlikuks võõrast majahaldjat, kes ei sallinud üleüldse võõraid. Sellepärast ei tohtinud viia last võõrasse majja ja käia temaga külas. Kui haiguse põhjuseks peeti ikkagi võõrast majahaldjat, viidi lapserõivad selle maja keldrisse, kus oli käidud koos lapsega. Hommikul toodi särk tagasi ja pandi voodisse lapse pea kõrvale. Lekma ülemjooksu Tõlõsi ja Gulekšuri küla bessermanid panid aga selle haiguse puhul lapse mütsi ja särgi ristatud keppide otsa ja asetasid ööseks lapsega külastatud maja värava kõrvale (AVM < Jukamenskoje raj, Gulekšuri k - J. I. Nevostrujeva, s 1921 (1995)). Viimastel aastatel on tekkinud ravimisviisid selleks puhuks, kui laps on haigestunud haiglahaldja mõjul. Kui haiglahaldjas on võtnud lapse halvasti vastu, võib ravi osutuda kasutuks. Sellepärast soovitatakse lapse haiglast äratoomisel lõigata kolmest põrandalauast kolm väikest pilbast, panna vette ja pesta selle veega lapse silmnägu (AVM < Jukamenskoje raj, Tõlõsi k - Z. I. Baltatšova, s 1929 (1995)).

Kui laps oli rakendatud meetmetest hoolimata ikkagi väga haige, koguni lausa surmasuus, viidi läbi "ostu-müügi rituaal". Laps "müüdi" sümboolse hinna eest hea tervise ja iseloomuga inimesele, kes läks koos temaga majast välja ning tuli mõne minuti pärast tuppa tagasi ja andis ta vanematele üle 
kui uue lapse, öeldes seejuures: Elagu minu õnne arvel! (AVM < Jari raj, Vortsa k - L. I. Djukina, s 1932 (1995)). Mõnikord sooritati haige "ost-müük" toas laua taga: vanemad müüsid ta uutele abikaasadest ristivanematele. Uued ristivanemad andsid lapsele uue nime ja andsid ta vanematele tagasi. Selline komme oli tuntud ka teistel Volga-äärsetel rahvastel (Atamanov 1985: 98; Fedjanovitš 1979: 84-85) ja mõne piirkonna venelastel (Sumtsov 1880: 69). Lapse soost olenevalt kutsuti "ostjaks" kas mees või naine, kellest sai lapse ristivanem. Uut ristivanemat kostitati, anti kingitus (tükk kangast, rätik, käterätt või särk), temasse suhtuti nagu teistessegi ristivanematesse, kuid need suhted olid aupaklikumad. Talle läksid üle kõik teiste tähtsad funktsioonid. See puudutas õigust osaleda ristilapse pulmas ja perekondlikel pidudel ning olla kutsutud sõjaväkke saatmise peole.

Bessermanid sooritasid raskelt haige lapsega ka prahi hulka viskamise rituaali (šakta vâle kušton). Nagu "ostu-müügi" puhulgi, kutsusid vanemad hea tervisega, kuid lapsega samast soost inimese. Võimaluse korral kutsuti üks kaksikutest. Enne tema tulekut pühiti toapraht läve kõrvale ja pandi selle peale paljas laps. Arvati, et koos prahiga sai ka haigus välja pühitud. Kui kutsutud inimene sisenes, palusid vanemad tõsta tal laps põrandalt, jagada talle oma tervist ja olla ristivanemaks:

Võta laps! Võta meie lapse haigused ära! Võta endale lapse nutud. Ole talle ristiemaks/ristiisaks.

Tulija võttis lapse kätele ja andis ta vanematele soovides tervist:

Jäta oma haigused ja nõrkus! Ole terve!

Rituaali peaeesmärk on uue ja terve lapse saamine. Bessermanidel ja põhjaudmurtidel sai rituaalis osalenud inimene lapse ristivanemaks ja temale laienesid kõik kaasvanemlusega seotud normid ja kombed nagu eelmiselgi juhul. Pärast seda rituaali võisid lapse vanemad ja ristivanemad nimetada teineteist kaasvanemateks nagu ristimisel. Nikolai Pervuhhin on märkinud põhjaudmurtide sellist rituaali kirjeldades õigesti, et see on ristimisest varasem komme, kuid kaasvanemate mõiste tekkis kindlasti alles koos ristiusustamisega ja kristlik tähendus omistati isikutele, kes olid tuntud juba enne ristiusku (Pervuhhin 1890: 37). Lapse "ostu-müügi” ja "prahi seest tagasisaamise" rituaalid on sisult lähedased ümbersünnitamisrituaalile. Nende rituaalide peamine eesmärk seisnes haige lapse asendamises uue ja tervega, kuid erinevalt ümbersünnitamisrituaalist sooritati neid peres ilma posija abita. Võimalik, et sellepärast on informatsioon nende kohta säilinud tunduvalt paremini, sest kombed on eksisteerinud üsna kaua perekonnatavandi osana. "Lapse tagasisaamist prahi seest" kasutasid bessermanid kogu asualal 
veel 1960. aastate keskel, praegu võidakse seda rakendada peredes, kus elab eakaid inimesi.

Haiguseks peeti lapse pidevat näljatunnet ja sagedast toidu küsimist. Sel juhul ütlesid täiskasvanud, et toidust ei ole kasu ja haigus tuleb "ära raiuda". Laps peideti puuküna alla ja raiuti selle peal vihta, koputati noa või kirvega. Lapsele öeldi:

Vaat, ma raiun sind küna all, kui küsid sü̈̈a! (AVM < Jukamenskoje raj, Žuvami k - V. P. Popov, s 1941 (1991)).

Usuti, et pärast "raiumist" saab laps terveks, toidust on kasu ja sööki läheb vaja täpselt nii palju, kui palju on tarvis normaalseks arenemiseks. Bessermanid "raiusid" sellisel viisil ka üht teist haigust, mida nimetati ačarvak. See tähendas, et imik ei võtnud emarinda suhu. Ravimiseks pandi ta põlvedele, kaeti künaga, toksiti kirvega ja öeldi:

Ö̈̈ tuli tagasi, päev tuli tagasi, päike tuli tagasi, kuu tuli tagasi. Saagu laps terveks. Raiun tema ačarvakki (AVM < Jukamenskoje raj, Ježovo k - T. I. Antuganova, s 1924 (1996)).

Udmurtidel ja komidel oli küna all "raiumise" rituaal elu ja surma piiril olevate laste ja täiskasvanute ravimise võte (Iljina \& Šabajev 1995: 118; Tšernõhh 1996: 295).

Naba paigast mineku ehk nabasonga ( $d e j$ ehk $u$ śie) kartuses ei lubatud poisslapsel kõva häälega nutta ja kõhulihaseid liialt pingutada. Laste songa raviti massaažiga, mis kujutas endast samaaegset sissehingamist ja vajutavaid liigutusi käe või väikeste esemetega. Näiteks tehti sissehingamisel nabast allapoole sõrmega rist. Oli ka teisi võtteid: nabast kõrgemale pandi näputäis kruupi, allapoole jahu, vasakule sütt ja paremale mulda ning vajutati kõigepealt vastu kruupe, siis jahu, sütt ja soola, s.o tehti jällegi rist. Kõhtu masseerides tehti naba piirkonnas vajutavaid liigutusi kedervarre otsa, tainarulli, tühja kudumistelgede pooli või suuraudadega. Pöidla või nimetissõrmega tehti naba ümber vastupäeva kolm ringi, määriti veskiratta tõrvaga. Kõhule naba kõrvale pandi üraski tõuk. Tõuk hammustas nahka ja see põhjustas lihaste kokkutõmbe. Kui laps pissis nende toimingute ajal, arvati, et ravimisvõte on õige. Poiste naba paikapanemiseks kutsuti mõnikord ka hobuseravitseja. Rahva seas oli märgatud, et poistel on nabasonga sagedamini kui tüdrukutel.

Bessermanidel on tänapäevani sälinud mitmed laste kogeluse ravimise meetodid. Seda haigust peeti kaasasündinuks (pärilikuks) või ehmumise tagajärjeks. Kogelevat last vannitati saunas, kus ta pandi kõhuli ja sirutati vasak jalg parema käe suunas ning parem jalg vasaku käe suunas. Arvati, et 
kui jalad-käed õnnestub kokku viia, on ka ravimisest kasu. Seejärel löödi last vihaga ja raputati vihalt vett ukse taha maha lausudes: Mingu kogelemine ära. Mingu lapse kogelemine ukse taha. Nagu teistelgi juhtudel, püüti anda haigus üle tervele täiskasvanule: pärast vannitamist ulatati haige laps läbi saunaakna sama nimega täiskasvanule ja paluti haigus ära võtta.

Naine võis kutsuda oma ema spetsiaalse "toitmisrituaali" sooritamiseks. Laps pandi istuma laua alla ja laua kohal liigutati kellukest. Seejärel pandi kellukese sisse putru või kaerakamajahu ja anti lapsele laua alla, kus ta selle ära sõi.

Kui laps kogeles vee ääres ehmumisest või vette kukkumisest, arvati, et teda hirmutas perekonna veehaldjas vu kuzjo. Siis korraldati ravimine kaldal. Kellukest hoiti lapse pea kohal ja pöörduti vu kuzjo poole palvega mitte ehmatada haiget. Seejärel toideti last kellukese sees oleva pudruga. Turtšino, Filimonovo ja Istošuri külas pandi rituaalne puder harakapessa. Samuti tegid ka põhjaudmurdid Tšeptsa paremal kaldal. Kellukese või harakapesa valimist seletati sellega, et laps pidi hakkama rääkima kõlavalt ja puhtalt nagu heliseb kelluke või kädistab harakas. Nõnda püüti patsiendile üle anda rituaalsete esemete omadused.

Rohke süljenõristuse korral "lõigati" lapse sülge kääridega, valati talle mööda kaelkooku vett suhu ja sooviti tervenemist. Vee valamisel oli valaja magamislavatsil, laps aga põrandal.

Voodimärgamise korral tuli haigus "kokku pigistada" või "kinni panna". Selleks lasti lapsel hommikul väravahingele kusta. Mõnikord kutsuti posija. Too palus last pissida kolmele pilpale, seejärel pani need lausudes ukselävele ja sulges ukse (AVM < Jukamenskoje raj, Turtšino k - J. G. Zjambahtina, s 1925 (1995)). Voodimärgamist seletati ehmatuse ja sünnitamisel liiga lühikeseks lõigatud nabanööriga. Haigus võis tekkida ka siis, kui laps astus kohale, kus oli seisnud kultusehitis vej kiśkan ('või valamise koht'). Sel juhul tuli kindlasti ohverdada sulavõid.

Rahvakalendris olid kõik ravimise ja järgmiseks aastaks tervise kindlustamisega seotud kombed koondunud kevadtsüklisse. Tervist aitas säästa ja haigusi ennetada laste osalemine mõnede rahvakalendri tähtpäevade kommetes.

Eriti huvitav oli burtčiń kertton ('siidniitide sidumine') suurel neljapäeval. Varahommikul külastasid lapsed sugulasi ja naabreid. Pererahvas soovis igale lapsele head tervist eelseisvaks majandusaastaks ja sidus laste käte külge värvilisi siidniite ja villast lõnga. Neid amulette kanti lihavõteteni või põllutööde algust tähistava rituaalini. Siis seoti niidid nuluoksa või pilpa külge ja saadeti pärijõge sõnadega: Viigu vesi meie haigused ära!, Võtku niidid meie haigused ära! Viimastel aastatel ei korraldata põllutööde alguse 
rituaale. Sellepärast saadavad lapsed niite jäämineku ajal või viskavad mõne päeva möödumisel pärast ringkäiku külas jõkke või ojja või seovad lehtpuude okste külge. Viimasel juhul jälgitakse hiljem puud. Kui puu kasvab hästi, on ka laps terve, puu kuivamine on halb enne.

Suurel neljapäeval enne päikesetõusu tehti õues õlgedest ja kadakaokstest väike lõke. Üle lõkke hüppasid kõik pereliikmed, imikuid viidi üle tule kätel, ulatati käest kätte, hoiti suitsu kohal. Haiged, kogelevad ja voodimärgajatest lapsed toodi kindlasti lõkke juurde. Last sunniti tule kohal kätt soojendama ja jalaga tuhale astuma. Lõkkest järelejäänud tuhk viidi küla taha ja arvati, et koos sellega lähevad ka kõik haigused ära. Viimastel aastatel püütakse seda rituaali läbi viia peredes, kus on haigeid lapsi.

Peale selle urbiti lapsi palmipuudepühal pajuokstega, püüdes sel viisil ajada nendest välja haigusi ja laiskust.

Paljude lastehaiguste objektiivne põhjus peitus muidugi eluolus. Veel 19. sajandil märkis vaimulik K. A. Satrapinski oma koguduseliikmete (udmurtide ja bessermanide) haiguste põhjusena viletsaid ja liiga õhukesi rõivaid, halba elukorda ja väheväärtuslikku taimtoitu. Ta kirjutas lastehaigustest, et

[---] lastel on erinevad lööbed, leetrid, rõuged, sarlakid ja peamiselt suvisel ajal suures koguses rohelise köögivilja tarvitamisest kõhulahtisus (Satrapinski 1854).

Olustiku muutumise ja meditsiiniasutuste tekkimisega kadusid vähehaaval paljud varem levinud lastehaigused, eriti nakkushaigused leetrid, rõuged, tüüfus jm. 20. sajandi teisel poolel jäeti osaliselt sellepärast unarusse ka need ravimeetodid, mis olid varem laialt levinud rahvaravitsejate ja ka täiskasvanud pereliikmete seas. Tänapäeval oskavad paljudest sellistest rääkida vaid vanad inimesed.

Perekondades on sälinud veel olmetasemel kaetuse, ehmumise, unetuse, külmetuste, haavandite ja mädaste haavade ravimised ning vahetatud lapse tagastamine. Kehtivad ka mõned keelud laste haiguse ajal, näiteks ei tohi majast asju välja anda ega loputada haige riideid voolavas vees. 20. sajandi keskpaigani kuulusid laste hügieeni ja imikute hooldamisega seotud teadmised ämmaemandate ravipraktikasse. Hiljem, kui hakati sünnitama haiglas, kutsuti neid vaid erakorralistel juhtudel, kui naist ei saadud viia haiglasse. Välitööd näitasid, et alates 20. sajandi keskpaigast tegelesid ämmaemandad põhiliselt vastsündinute hooldamise ja ravimisega. Nende tööülesannete hulka kuulusid lapse vannitamine esimestel päevadel pärast haiglast tulekut, lapse pea korrigeerimine, massaaž, songa, ehmumise ja kaetuse ravimine ning harjaste võtmine. 
Bessermani ämmaemandad ja posijad ravisid mitte ainult oma küla inimesi, vaid neid kutsuti sageli ka mujale, k.a vene, udmurdi ja tatari küladesse. Bessermanid säilitasid naabritest rohkem rahvameditsiini, eriti laste ravimise võtteid ja meetodeid. Ei saa olla juhus, et bessermanide kompaktsel asualal peetakse neid headeks ravitsejateks ja posijateks, ka kogenud nõidadeks ja teadjameesteks. Segakülades olid laste ravitsejad peamiselt bessermanid. Informandid seletasid seda asjaoluga, et bessermanid säilitasid naabritest kauem traditsioonilised uskumused, kultuuri ja ka rahvameditsiinialased teadmised. Tuleb märkida, et vaatamata traditsiooni püsimisele säilisid posijate ja ämmaemandate teadmised ja võtted bessermanidel isegi halvemini kui perekonna ravimiskombed. Sellepärast on suuremal määral ununenud teadmised nõiduse tagajärgede ja lastesonga ravimisest, haigusevaimu (per) ja hinge (urt) tagasisaamise rituaalist, uue lapse saamisest ehk teisisõnu - keerulise mütoloogilise taustaga haigused ja ravivõtted. Vanemad inimesed, kes teavad neid kombeid hästi, ei tegele haiguste ravimisega, et mitte teha lapsele veel rohkem kahju.

Lastehaiguste ravimise ja haiguste profülaktika võtted ja meetodid ei erinenud oluliselt täiskasvanute ravist, kuid mõned detailid andsid neile teatud omapära. See spetsiifika oli seotud ealiste eripärade ja ettekujutustega sellest, et laps on nõrgem ja abitum. Paljud ravimisvõtted arvestasid laste piiripealse seisundiga, mispärast olulise osa neist moodustasid täiskasvanud inimeselt tervise ülevõtmine ja "uue" sünni rituaal. Suurim hulk kombeid ja tavasid oli seotud imikueaga, eriti esimeste elukuudega, sest nendest sõltus lapse tervis tulevikus. Peab rõhutama, et praegustes laste ravimise meetodites on säilinud varem täiskasvanute ravimisel laialt kasutatud toiminguid. Analüüsides imikueaga seotud rahvameditsiini võtteid, tuleb märkida, et need sarnanevad udmurtide ravimis- ja hooldamismeetoditega. Võimalik, et see sarnasus oli suurel määral tingitud ühiselementidest majanduslikus korras ja elulaadis, uskumustes, mütoloogilistes ettekujutustes ümbritsevast maailmast ja sellest, milline koht oli seal lapsel. Analoogiad Uuralite ja Volga regiooni paljude rahvaste etnopediaatrias on seletatavad ilmselt looduslik-kliimaliste ja sotsiaal-ökonoomiliste faktorite sarnasusega, sest nende alusel kujunesid ka etnilised traditsioonid.

Lastehaiguste ravimine ja laste hooldamise traditsioonilised meetodid eeskätt sünnitsüklis ja lapse esimesel eluaastal on jätkuvalt osa perekonnakombestikust. Paljud rituaalid moodustavad praegugi rahvameditsiini kohustuslike teadmiste kompleksi, mida valdavad mitte ainult rahvaravitsejad, vaid need on üsna laialt kasutusel ka tavalises bessermani maaperes.

Tõlkinud Nikolai Kuznetsov 
Jelena Popova

\begin{abstract}
Allikad
AVM = autori bessermanide juures korraldatud välitööde materjalid aastatest 19862000

UAKKI arhiiv = Udmurdi Ajaloo, Keele ja Kirjanduse Instituudi arhiiv

VEM = Peterburis asuva Vene Etnograafiamuuseumi kogu

VTAA = Venemaa Teaduste Akadeemia Arhiiv
\end{abstract}

\title{
Kirjandus
}

Atamanov 1985 = Атаманов Михаил Г. Обряды и поверья удмуртов, связанные с именами. Гришкина, Маргарита \& Майер, Вильгелм \& Христолюбова, Людмила (toim). Семейный и общественный быт удлуртов в XVIII-XX въ. Устинов: НИИ при СМ УАССР, lk 91-106.

Baiburin 1983 = Байбурин, Альберт К. Жилище в обрядах и представлениях восточныхх славян. Ленинград: Наука.

Belitser 1947 = Белицер, Вера Николаевна. K вопросу о происхождении бесермян (по материалам одежды). Труды института этнографии. Новая серия 1. Москва: Издательство Академии Наук СССР, lk 183-193.

Fedjanovitš 1979 = Федянович Тамара П. Мордовские народные обряды, связанные с рождением ребенка (конец XIX - 70-е гг. XX в.). Советская этнография 2 , lk 7989.

Ilina \& Šabajev 1985 = Ильина, Ирина В. \& Шабаев, Юрий П. Баня в традиционном быту коми. Вопросы этнографии народа коли. Труды Института языка, литература и истории Коми научного центра УрО РАН 32. Сыктывкар, lk 109-119.

Maksimov 1925 = Максимов В. А. Вотяки: Краткий историко-этнографический очерк. Ижевск: Удкнига.

Nalimov 1991 = Налимов Василий П. К вопросу о первобытных отношениях полов у зырян. Конаков, Николай Д. et al. (toim). Селья и социальная организация финноугорских народов. Труды Института языка, литературы и истории Коми научного центра УрО РАН 49. Сыктывкар, lk 5-23.

Nikitina 1992 = Никитина Галина А. Возрастные циклы в народной педагогике удмуртов. Вестник Удлуртского униъерситета $=$ научно-публичистический журнал $6, \mathrm{lk} 39-46$.

Nikolski 1919 = Никольский, Николай В. Сборник исторических материалов о народностях Поволжья. Казань: Издательско-переводческий подотдел МАРИ.

Pervuhhin $1890=$ Первухин Николай Г. Эскизы преданий и быта инородиеь Глазовского уезда: Следы языческой древности в суеверных обрядах обыденной жизни вотяков от колыбели до могилы. Эскиз V. Вятка. 
Laste hooldamise ja lastehaiguste ravimise traditsioonilised viisid bessermanidel

Satrapinski 1854 = Сатрапинский K. А. Вотяки и бесермяне, проживающие в приходе и селе Укан Глазовского уезда. Käsikiri Venemaa Geograafiaseltsi arhiivis ( $А$ Ахиъ Русского географического общщества), kategooria X, nimistu 1, säilik 48, L 5p.

Sumtsov 1880 = Сумцовъ, Николай. О славянскихъ народныхъ воссреніяхъ на новорожденного ребенка. Журналъ Министерства Народного Просвещенія CCXII. С.Петербург, lk 68-94.

Šabajev \& Šabajeva 1995 = Шабаев, Юрий П. \& Шабаева, Н. Ю. Баня в верованиях и представлениях русских, коми и удмуртов. Финно-угроведение 2, lk 51-63.

Šteinfeld $1894=$ Штейнфельд Н. П. Бесермяне: Опыт этнографического исследования. Календарь и палятная книжка Вятской вубернии на 1895 год. Вятка, $\mathrm{lk}$ 220-295.

Zelenin 1916 = Зеленин, Дмитрий К. Очерки русской мифологии 1. Петербург.

Tšernõhh 1996 = Черных А. В. Обряды и поверья, связанные с рождением ребенка у куединских удмуртов. Савелева, Элеонора et al. (toim). Христианизаиия коли края и ее роль в развитии государственности и культуры 1. Сыктывкар: Коми научный центр УрО РАН, lk 291-296.

Vereštšagin, Grigori. Käsikiri Venemaa Teaduste Akadeemia Arhiivis Peterburis, fond 135, nimistu 2, säilik 79 .

Vladõkin 1994 = Владыкин, Владимир Е. Религиозно-лифоловическая картина удлирmов. Ижевск: Удмуртия.

Vladõkina 1992 = Владыкина, Татьяна Г. Удмуртские поверья в системе этносоциальной регламентации. Никитина, Галина \& Трофимова, Елена \& Шкляев, Григорий (toim). Традиционное поведение и общение удмуртов. Ижевск: Российская академия наук, Уральское отд-ние, Удмурдский институт истории, языка и литературы, lk 126-170.

Wichmann Yrjö 1893. Wotjakische Sprachproben 1: Lieder, Gebete und Zaubersprüche. Suomalaisen-ugrilaisen seuran Aikakauskirja 11: 1. Helsingfors: Suomalaisen kirjallisuuden seuran kirjapaino. 


\title{
Summary
}

\section{Traditional Childcare and Treatment of Children's Diseases among the Besermian}

\author{
Yelena Popova
}

Key words: labour, folk medicine, children's diseases, mythological diseases, midwife, healer, Besermian

The article is based on fieldwork conducted during 1986-2000 among the Besermian (a small ethnic group in North-East Udmurtia, the districts of Iukamen, Iar, Balezino and Glazov, and the Cheptsa watershed). The article overviews the beliefs, customs and healing practices related to labour, care of the mother and the newborn.

A child is not completely physically formed by the time it is born, and its arrival in this world does not mean that labour is over. Owing to this reason, the child had to be "completed". In the first weeks and months, attempts to achieve the child's correct physical shape were made. This applied particularly to premature babies. A prematurely born baby was wrapped in sheepskin, held in a fur coat's sleeve, or warmed on the oven until it turned nine months old, so that the child could "become ripe". In the first few months after it was born, the newborn lied in the cradle. Women usually continued with their household duties already in the first few days following childbirth, and partook in field chores far away from home, in the field or woods. To be able to take care of and nurse the child, women took it along. Children were carried in various specially designed rucksacks.

A separate group of taboos and beliefs is associated with children's clothes, especially to designing, wearing, keeping and washing the clothes.

In everyday life, the rules that were concerned with possible harm to the child's personality, behaviour and fate were strictly observed. For example, it was forbidden to put kitchen utensils, especially sieves, on one's head during play, as it was believed that a child would remain short. An infant was not shown a mirror, otherwise it might sleep restlessly.

The basic food of infants was breast milk, and since feeding was irregular, the child was fed when it was hungry or cried. Breast milk remained a child's basic food until it turned two or three years old, or until the next child was born.

Also, Besermian midwives and verbal healers and their practices are reviewed. The Besermian retained traditional medicine longer than the neighbouring groups, especially as regards the methods for treating children. Diseases and healing practices of complex mythological background are gradually forgotten, knowledge and practices passed on within a family have survived better. Children's diseases and prophylactics are treated similarly to these of adults. Receiving health from an adult and the ritual of "new" birth played an important role. 